\title{
BREACHING THE PRINCIPLES OF CORPORATE SOCIAL RESPONSIBILITY AND RULES OF THE SHARING ECONOMY IN THE PASSENGER TRANSPORT SERVICES MARKET
}

\author{
JUSTYNA ŁAPIŃSKA, ${ }^{1}$ JAROSŁAW WOJTAS, ${ }^{2}$ MAURYCY GRASZEWICZ3 \\ ${ }^{1}$ Nicolaus Copernicus University in Toruń, POLAND \\ e-mail: justlap@umk.pl \\ ${ }^{2}$ Nicolaus Copernicus University in Toruń, POLAND \\ e-mail: j.wojtas@doktorant.umk.pl \\ ${ }^{3}$ SWPS University of Social Sciences and Humanities, POLAND \\ e-mail: mgraszewicz1@swps.edu.pl
}

RECEIVED
ACCEPTED
JEL
CLASSIFICATION

KEYWORDS

ABSTRACT
9 August 2017

15 December 2017

A11, M14, R49

Corporate Social Responsibility, sharing economy, transport services

The purpose of this paper is to analyse and evaluate business activities of the Uber company which declares itself as a sharing economy subject. The analysis is performed in the context of compliance with the principles of Corporate Social Responsibility (CSR), and the rules that should be followed by economic subjects operating under the sharing economy. Uber matches people who want to offer a transportation service with people who want to use this service. For this purpose, the company uses online applications. On the passenger transport market, it creates very serious competition for taxi corporations. The research carried out shows that the company has seriously violated the principles of CSR and the rules that should apply to subjects of the shared economy. Uber has enabled them to bypass tax regulations, passenger safety regulations and labour standards.

\section{Introduction}

The development of the Internet, new technologies and social media has contributed to the dynamic development of the so-called new economy, which is based on sharing. The sharing economy is also referred to in the literature as a peer-to-peer, mesh, or collaborative economy. It is a system built around the distribution of human and material resources, including the joint creation, production, distribution and consumption of goods 
and services by people and organizations. It includes both disinterested sharing of goods as well as renting out the possessed goods or resources (Banaszek, 2016). The positive consequences of the activity that, is part of the economy of sharing have been recognized by the European Commission. It has given its go-ahead to the issue of the development of collaborative consumption.

The concept of the sharing economy is incorporated into the idea of sustainable development, which aims to achieve a model of the exploitation of natural resources, investment and the creation of technology that will increase the economic, natural and social foundations of the needs of the present and future generations. (Czech, 2014, Łapińska, Huterska, Łapiński, 2017). The concept of corporate social responsibility is a systematic response to the challenges of sustainable development. The concept of CSR is considered to be an autonomous development model, useful in solving social, economic and environmental problems (Ziółkowski, 2012; Huterska, 2017).

\section{The objective of the study, material and method}

The purpose of this study is to analyse and evaluate business activities of the Uber company that declares its operation within the sharing economy system, in the context of compliance with the Corporate Social Responsibility (CSR) catalogue of principles, and the rules that should be followed by entities operating under the sharing economy. This article briefly outlines the origins and functioning of the Uber platform. It also presents its relationships with the environment. The major methods employed in the study are the case study method, descriptive analysis as well as institutional and legal analysis. Secondary sources of information such as PricewaterhouseCoopers reports, the UOKiK's (the Office of Competition and Consumer Protection) stance and deputies' questions were used. The source collection also includes press materials, since studies on entities operating under the sharing economy in Poland are novel and have not been satisfactorily presented in the subject literature yet.

\section{The concepts of sustainable development and social responsibility and the development of the sharing economy - selected theoretical aspects}

Changes in the environment, consisting in increasing the number of threats that have been the result of civilization progress, have contributed significantly to the emergence of the concept of sustainable development. This concept emphasizes that development should lead to meeting the needs of present generations without endangering the needs of future generations (World Commission on Environment and Development, 1991). This concept emphasizes the non-economic aspects of the functioning of enterprises and above all environmental protection and the quality of life of society. These are values that fit in with the general well-being of society.

The emergence of a sustainable development concept, the implementation of which in the face of the dangers of civilization development has become a necessity, undoubtedly, contributed to the development of the concept of corporate social responsibility. H.R. Bowen (1953), who is recognized as the father of CSR, defined the social responsibility of entrepreneurs as the duty of policymaking, decision-making and the realization of activities that are in line with social expectations. Corporate Social Responsibility is also defined by the World Business Council for Sustainable Development, according to which, it is a continuous commitment of business to ethical behaviour and to contributing to sustainable economic development by improving the quality of life for workers and their families as well as the local community and society as a whole (World Business Council for Sustainable Development, 1998). The subject literature (see, for example, Julewicz, Ejdys, 2009; Huterska, Huterski, 2014) emphasizes that, 
in relation to sustainable development, a socially responsible company should ensure a balance between activities aimed at the achievement of economic, social, and environmental purposes.

The essence of social responsibility also includes the ISO 26000, Social Responsibility Guidelines (ISO $26000,2010)$, which defines it as the organization's responsibility for the impact of its decisions and actions on society and the environment. This responsibility is a transparent and ethical behaviour that contributes to sustainable development including prosperity and public health.

The ISO 26000 standard also refers to several important principles of social responsibility that should be respected by companies operating under the concept of CSR, i.e., liability, transparency, ethics, respect for stakeholder rights, respect for the law, respect for international standards of conducting business activity as well as respect for human rights. Therefore, the concept of CSR emphasises the responsibility of business in relation to the broadly understood environment. In general, it emphasizes the influence of the organization's activities on improving the quality of life of society.

Despite the development of the CSR idea and the growing number of its supporters, there are also critical views of this concept. Authors expressing critical opinions on the concept (Doane, 2005; Doda, 2015) highlight also the cost aspects related to undertaking socially responsible actions, the lack of genuine motivation and sometimes even the lack of effects of these actions. They point out that quite frequently social responsibility is a tool that only enhances the image of the organization, and that society perceives it as diverting attention by 'socially responsible' companies from other, more serious problems (Roszkowska, 2011). As a result, many authors (Grzybowski, 2004; Goel, Ramanathan, 2014) emphasize that corporate social responsibility is a philosophy of profit making and cannot be looked at as a tool for building the desired image.

The subject literature (see, for instance, Griffin, 2004; Wolska, 2015) emphasises that organizations may exhibit varying degrees of involvement in social responsibility issues, from a complete lack of interest in activities that contribute to solving social or environmental problems to highly active attitudes of seeking opportunities to contribute to the creation of social good.

The most desirable active attitude is not only conscious acceptance of the organization's responsibility for the consequences of its decisions and actions, but also the inclusion of social issues in the strategy-building process. As rightly highlighted by Ślęzak-Gładzik (2013), to fully utilize the concept of CSR in practice, it is necessary to change the mindset and replace individual actions referred to as CSR with a comprehensive approach to social responsibility. What counts in responsible business is a strategic and long-term approach based on the principles of social dialogue and the search for good solutions for all (Rok, 2012).

To a certain extent, the concept of the sharing economy is embedded in the concept of sustainable development and social responsibility. It involves matching people (via online platforms) to enable them to provide services or share resources, time, skills or capital without transferring ownership rights. The essence of this phenomenon is the ability of private individuals to use their resources - mainly real estate and vehicles - to compete with traditional entrepreneurs. Thus, a relatively large number of prosumer groups i.e., consumers and producers combined, have emerged that have access to an extremely wide audience (PricewaterhouseCoopers, 2016).

The objective of the sharing economy is to use resources in the most effective way with the assumption of reducing social and environmental costs (Rifkin, 2016). This concerns, in particular, passenger transport, as the use of motor vehicles is highly inefficient nowadays. Shared use of vehicles significantly increases this efficiency and improves the quality of life in urban centres where parking spaces are scarce. It is also worth noting that some 
positive aspects result from the sheer fact of matching strangers. This contributes to an increase in trust that, though difficult to estimate, is an essential aspect of social life.

\section{Causes of the controversy around the Uber company}

Uber was created as an internet platform. Its purpose was to communicate self-employed persons using their own vehicles during their free time to provide passenger transport services with customers. For this purpose, an application to be used in computers and mobile devices was developed. The company operates in more than 330 cities in the world and is valued at 51 billion USD. It also offers its services in Poland, among others in Warsaw, Cracow, Wrockaw, Silesia and the Tricity. The company started to operate on the Polish passenger transport services market in 2014. From the very beginning of its functioning, it has been causing controversy. Because of its controversial and often illegal practices, it has already been banned in several European cities such as, for instance, Berlin (Kell, Smith, 2014) or Barcelona (Mount, 2014). Spain, Belgium, and France have banned the internet application, and bringing it back is dependent on compliance with the national legislations.

In Poland, the reluctance and often hostile reactions to drivers cooperating with the company and providing services identical to the decades-old taxi corporations have been triggered not by the competition itself, but by the unregulated business practices that favoured entities operating under the shared economy.

Controversy was also aroused by the fact that the Polish branch office was registered in the Netherlands. Competitors argue that the choice was made to exploit the loopholes in the tax legislation and to abuse the existing favourable conditions for e-economy entities (Polska Agencja Prasowa, 2017). These practices have led to a conviction that the business owners intend to dominate the passenger transport market by means of wage dumping. This is done on the basis of unfair competition and with the aim of eliminating, in this case, weaker entities but complying with the applicable regulations. Similar practices have already taken place in Spain and France as well as in the USA.

Uber is characterized by a specific business model. Significant is the fact that drivers are not hired by the company, so they are not its employees. They only sign a civil law contract for the use of an application that only mediates between the driver and the customer. Uber drivers carry out their work without a license for transport services, without additional passenger insurance, without cash registers and other restrictions imposed on drivers affiliated to taxi corporations. The facts presented undoubtedly undermine the CSR principles. Moreover, arguments are raised that the Polish law regulations are being violated. As a result, taxi drivers make civic arrests, which they believe to be right. There were reported even some cases of violent attacks on Uber drivers (Szulc, 2017).

\section{The uberisation process}

The phenomenon of making the rules of cooperation more flexible and transferring responsibility for the service performed from the employer to the employee is not in compliance with the CSR principles. In the context of Uber's operations, such practices have even been named as 'uberisation' (Nurvala, 2015). Uber is very selective about applying the principles of the shared economy, while enjoying the positive atmosphere that accompanies its development.

The fact of the misuse of the principles of the shared economy has already been debated by parliamentarians who had been alerted by taxi corporations and Uber adversaries. Taxi corporations and Uber adversaries were supported by representatives of almost all political options of the Polish Parliament. Interpellation no. 10,362 filed 
by MP Piotr Marzec got much media coverage due to its substantive content. "Uber is trying to promote itself as an alternative to taxi services, based on the so-called sharing economy (...) the phenomenon covering both rendering direct services as well as sharing, co-creating, co-producing, buying jointly based on the human tendency to cooperate, help others and share their time and resources, which is reciprocated in a variety of ways" (Marzec, 2017). The above-mentioned aspects of the shared economy clearly emphasize the characteristics of its subjects. The objective is providing services, not compensation for intermediation. The author also wrote that: "Contrary to the principles of the shared economy characterized by the lack of payment and the provision of services on the basis of companionship or exchange of services or mutual courtesy, each passenger transport service performed by Uber using its associated drivers incurs a fare that is automatically collected from the passenger's credit card" (Marzec, 2017). The interpellation rightly pointed to the need to pay a fare, which is against the non-profit principle. It is quite different, for instance, from the BlaBlaCar platform ${ }^{1}$ which clearly defines the costs borne jointly by the vehicle owner and the passenger which depend on the parameters and possibly on the place where the order was made. The BlaBlaCar driver may waive the charge, Uber always charges the customer directly.

Due to the protests taking place in several Polish cities, the media have started a debate on the ubersiation of work. An opinion expressed by of one of the journalists can be deemed to be the right conclusion on this ongoing debate: "Undoubtedly, taxi drivers are fighting against a corporation that uses wage dumping. But they are also fighting against the practice of avoiding paying taxes and lowering the standards of work in our country. (...) In theory, this is an exchange of services between people, but behind this venture is a large corporation that is taking profits. Drivers have to share their earned money with Uber only due to the fact that they use its application" (Syska, 2017).

Among the many emotional arguments that have gained much media coverage, those presented by Syska (2017) are the substance of the allegations against the company. They emphasise the issue of Uber drivers who have often come from Ukraine for work purposes and perform work under civil law contracts below the mandatory minimum hourly rate used in Poland. The practice of exploiting the difficult situation of economic immigrants is extremely controversial and certainly unethical. Their long hours work also translates into the number of traffic accidents caused by them.

\section{Conclusion}

The sharing economy is a combination of individuals and legal entities through online platforms in a way to enable them to provide services or to share assets, resources, time, skills, or capital. This is generally done in a limited time and always without transfer of ownership. As a part of the sharing economy, passenger transport services are developing very well, thus contributing to a significantly more efficient use of passenger cars. The Uber company can be classified as an economic subject that operates under the sharing economy. The company matches those who want to offer transport services with people who want to use the service. The aim of the paper was to analyse Uber's business activity in the context of the compliance with the principles of CSR and the practice of the sharing economy. The study carried out shows that the Uber company has seriously violated these principles. Through the implementation of its Internet platform, it has enabled service performers to avoid taxes, regulations

${ }^{1}$ BlaBlaCar is a French-based online platform for communicating drivers who provide free seats in their cars in exchange for fuel costs contributions. 
on passenger safety and standards of work. Also, it has caused social unrest and led to protests that paralysed the largest Polish cities. Moreover, Uber has breached the Polish law and ethical standards.

\section{Acknowledgement}

The paper was developed as part of the project "Positive social change in an organization as a factor of a company engagement in sustainable development". The project was funded by the National Science Centre, Poland, on the decision number DEC-2017/25/B/HS4/01113.

\section{References}

Banaszek, M. (2016). Ekonomia współdzielenia jako alternatywny kierunek rozwoju miast. Ekonomia Społeczna, 1, 51-59.

Bowen, H.R. (1953). Social responsibility of the businessman. New York: Harper\&Row.

Czech, K. (2014). Znaczenie zielonej gospodarki dla realizacji celów zrównoważonego rozwoju. In: A. Budnikowski, A. Kuźniar (eds.), Nowe procesy w gospodarce światowej. Wnioski dla Polski. Warszawa: Szkoła Główna Handlowa w Warszawie - Oficyna Wydawnicza.

Doane, D. (2005). The myth of CSR: the problem with assuming that companies can do well while also doing good is that markets don't really work that way. Stanford, CA: Stanford Graduate School of Business.

Doda, S. (2015). The Importance of Corporate Social Responsibility. Journal of Sociological Research, 6 (1), 86-91.

Goel, M., Ramanathan, P.E. (2014). Business Ethics and Corporate Social Responsibility - Is there a Dividing Line? Procedia Economics and Finance, 11, 49-59.

Griffin, R.W. (2004). Podstawy zarządzania organizacjami. Warszawa: Wydawnictwo Naukowe PWN.

Grzybowski, M. (2004). Firma odpowiedzialna społecznie. Filozofia przedsiębiorstwa XXI wieku. In: T. Kamiński, W. Pomykało (eds.), Społeczna odpowiedzialność współczesnego marketingu. Materiały konferencyjne. Warszawa: Fundacja Innowacja.

Huterska, A. (2017). Public-Private Partnership in Building Sustainable Development of the Kuyavian-Pomeranian Voivodship. European Journal of Interdisciplinary Studies, 9 (1), 7-12.

Huterska, A., Huterski, R. (2014). Wykorzystanie podatku od nieruchomości dla zrównoważonego rozwoju miast na przykładzie Torunia. Prace Naukowe Uniwersytetu Ekonomicznego we Wrocławiu, 330, 135-147.

ISO 26000 (2010). Guidance on social responsibility. Retrieved from: http://www.cnis.gov.cn/wzgg/201405/P020140512224950899020. pdf (16.06.2017).

Julewicz, A., Ejdys, J. (2009). Korzyści społecznej odpowiedzialności biznesu. Ekonomika i Organizacja Przedsiębiorstwa, 6, 66-74.

Kell, J., Smith, G. (2014). Berlin bans Uber app, citing passenger safety concerns. Fortune, 14.08.2014. Retrieved from: http://fortune. com/2014/08/14/uber-berlin-band (18.06.2017).

Łapińska, J., Huterska, A., Łapiński, P. (2017). The financial effects of investments realised under sustainable development - the case of a Polish company representing the rendering industry. Roczniki Naukowe Stowarzyszenia Ekonomistów Rolnictwa i Agrobiznesu, XIX (1), 99-103.

Marzec, P. (2017). Interpelacja poselska, No. 10362, Retrieved from: http://www.sejm.gov.pl/sejm8.nsf/interpelacja.xsp?typ=INT\&nr= 10362 (19.06.2017).

Mount, I. (2014). Airbnb. Uber under attack in Barcelona. Retrieved from: http://fortune.com/2014/05/28/airbnb-uber-barcelona (19.06.2017).

Nurvala, J. (2015). Uberisation is the future of the digitalised labour market. European View, 14 (2), 231-239.

Polska Agencja Prasowa (2017). Taksówkarze protestowali przeciwko działalności nielegalnych przewoźników. Retrieved from: http://www.pap.pl/aktualnosci/news,962890,taksowkarze-protestowali-przeciwko-dzialalnosci-nielegalnych-przewoznikow. html?pdf=2 (17.06.2017).

PricewaterhouseCoopers (2016). (Współ)dziel i rządź! Twój nowy model biznesowy jeszcze nie istnieje. Part I. Retrieved from: https:/l www.pwc.pl/pl/pdf/ekonomia-wspoldzielenia-1-raport-pwc.pdf (19.06.2017).

Rifkin, J. (2016). The Zero Marginal Cost Society. The Internet of Things, the Collaborative Commons, and the Eclipse of Capitalism. New York: Palgrave Macmillan. 
Rok, B. (2012). Społeczna odpowiedzialność biznesu. In: W. Gasparski (ed.), Biznes, etyka, odpowiedzialność. Warszawa: Wydawnictwo Profesjonalne PWN.

Roszkowska, P. (2011). Rewolucja w raportowaniu biznesowym. Interesariusze, konkurencyjność, społeczna odpowiedzialność. Warszawa: Difin.

Syska, M. (2017). Uber szkodzi nam wszystkim. Retrieved from: http://www.se.pl/wiadomosci/opinie/syska-uber-zagraza-namwszystkim_999129.html, (16.06.2017).

Szulc, A. (2017). Polowanie na Ubera. Krakowscy taksówkarze stworzyli grupę pościgową. Retrieved from: http://www.newsweek.pl/ polska/spoleczenstwo/uber-krakowscy-taksowkarze-scigaja-kierowcow-ubera,artykuly,407902,1.html (15.06.2017).

Ślęzak-Gładzik, I. (2013). Corporate Social Responsibility (CSR) jako koncepcja porządkująca relacje między biznesem a społeczeństwem. Modern Management Review, 20 (2), 113-125.

The Office of Competition and Consumer Protection (2016). Uber - Statament of UOKIK's Position, 5.05.2016. Retrieved from: https:// uokik.gov.pl/news.php?news_id=12353 (19.06.2017).

Wolska, G. (2015). Zaangażowanie przedsiębiorstw w realizację koncepcji społecznej odpowiedzialności na podstawie badań empirycznych przeprowadzonych w Polsce. Studia Ekonomiczne. Zeszyty Naukowe Uniwersytetu Ekonomicznego w Katowicach, 236, 85-95.

World Business Council for Sustainable Development (1998). Meeting Changing Expectations - Corporate Social Responsibility. The Netherlands, WBCSD Stakeholder Dialogue on CSR. Retrieved from: https://growthorientedsustainableentrepreneurship.files. wordpress.com/2016/07/csr-wbcsd-csr-primer.pdf (17.06.2017).

World Commission on Environment and Development (1991). Nasza wspólna przyszłość. Raport Światowej Komisji do Spraw Środowiska i Rozwoju. Warszawa: Państwowe Wydawnictwo Ekonomiczne.

Ziółkowski, B. (2012). Ewolucyjne podejście do ekoinnowacji i zrównoważonego rozwoju - ujęcie systemowe. Rzeszów: Wydawnictwo Bonus Liber.

Cite this article aS: Łapińska, J., Wojtas, J., Graszewicz, M. (2018). Breaching the principles of corporate social responsibility and rules of the sharing economy in the passenger transport services market. European Journal of Service Management, 1 (25), 157-163. DOI: 10.18276/ejsm.2018.25-19. 